\title{
The seniors boom and economic repercussions: Waterloo Region economic development opportunities for growth in an aging society
}

\author{
Tracy Suerich, MPS
}

\begin{abstract}
The population in Canada is aging, and even the 'Silicon Valley of the North' Waterloo Region is no exception. Aging societies can have a positive impact on the Economy; however, proper policies and programs must be in place in order to thrive through the peak of the Baby Boom retirement wave in 2026. This paper discusses research and recommendations from literature reviews and best practices found among municipalities regarding methods to thrive in an aging society. It is hoped that this paper will aid economic developers and supporting organizations to prepare for the impending age shift through adapting new employment, service, and built environment policies and programs. Adapting economic development now may prevent future economic downturns due to changes in work, lifestyle, and spending habits that are expected throughout the aging and retirement of the baby boom generation.
\end{abstract}

Keywords: Older adults, senior, caregiver, age friendly, anti-aging, adaptive employment

\section{Introduction}

Over twenty years ago, David Foot (1996) shook the foundations of Economic Development with his book Boom, Bust \& Echo. In its pages, Foot shone a light on the coming effect of the Baby Boom generation on the economy (i.e., people born between 1946 and 1964). In the years since its publication a lot has changed, yet a lot has stayed the same regarding how we need to prepare for this aging society. The last of the baby boomers born at the peak of the trend will be turning 65 just prior to 2030. Though we have been experiencing the effects of baby boomers entering retirement throughout this decade, there remains time to prepare our economies for the longer-term effects of our aging population.

Waterloo Region is a hotbed for technological innovations and young entrepreneurs, however, this does not protect it from the potential downfalls of an aging society. By 2033, over 30 per cent of the region's population will be over the age of 55, that is nearly double the current demography (Norris, 2013). This paper proposes methods for thriving in the face of an aging society while continuing to grow Waterloo Region's reputation as 'Silicon North'.

This paper will review three main opportunities for economic development in an aging society: spending, services, and employment. An overview of demographic trends, health and lifestyle 
impacts on spending, and age friendly communities will be provided before exploring literature and best practices in support of these opportunities. This paper will then provide specific methods that the municipalities and townships across the Region of Waterloo can pursue to develop each of these focus areas. With extra effort now, the Region can expect to come out of the baby boom wave of aging and retirement much stronger than municipalities that focus on innovation and emerging markets alone.

\section{Demographic trends}

Waterloo Region is considered to be among the younger communities in Canada. It has a high number of post secondary institutions per-capita and high quality of life which generally contribute to its lower than average age base (Region of Waterloo, 2019). Waterloo Region, also boasts fewer low-income seniors per capita than the Ontario average, meaning that the older adults who do live in this area have increased spending potential (Region of Waterloo, 2011).

Waterloo Region CMA has a total population of 523,894, from this total the most recent census finds that 14.5 per cent of the population is over the age of 65 (Statistics Canada, 2017a). This age group is henceforth referred to as older adult. Table 1.1 further breaks down the older adult population by age group in order to contextualize discussion around employment and spending patterns among older adults throughout this paper.

Table 1.1. Older adult population by age group in Waterloo Region CMA

\begin{tabular}{|c|l|}
\hline 65 to 69 years & 24,074 \\
\hline 70 to 74 years & 17,472 \\
\hline 75 to 79 years & 12,620 \\
\hline 80 to 84 years & 9,236 \\
\hline 85 to 89 years & 6,113 \\
\hline 90 years and over & 3,386 \\
\hline Source: Statistics Canada, (2017b).Table 051-0056 Estimates of population by census metropolitan area, sex and \\
\hline ge group for July 1, based on the Standard Geographical Classification (SGC) 2011.
\end{tabular}

The Region of Waterloo is projecting a 'seniors boom' that will affect the economy through 2031 (Region of Waterloo, 2011). Furthermore, adults over the age of 75 are the fastest growing 
part of this population due to increased life expectancy among older adults, but older adults are also living longer with chronic diseases such as obesity, diabetes, and high blood pressure rates (Region of Waterloo, 2011).

\section{Aging in the workforce and entrepreneurship}

In 2001, over 300,000 Canadians aged 65+ were participating in the labour force (Public Health Agency of Canada, 2006). Since that time there has been an increasing trend of continuing to work later in life. Table 2.1 shows an increase in older adults in the workforce beginning 2001 as the baby boom generation entered into this age bracket, and a secondary jump with the abolishment of mandatory retirement age in 2006 (Hicks, 2015).

Table 2.1. Employment among people aged 60 to 69 by gender

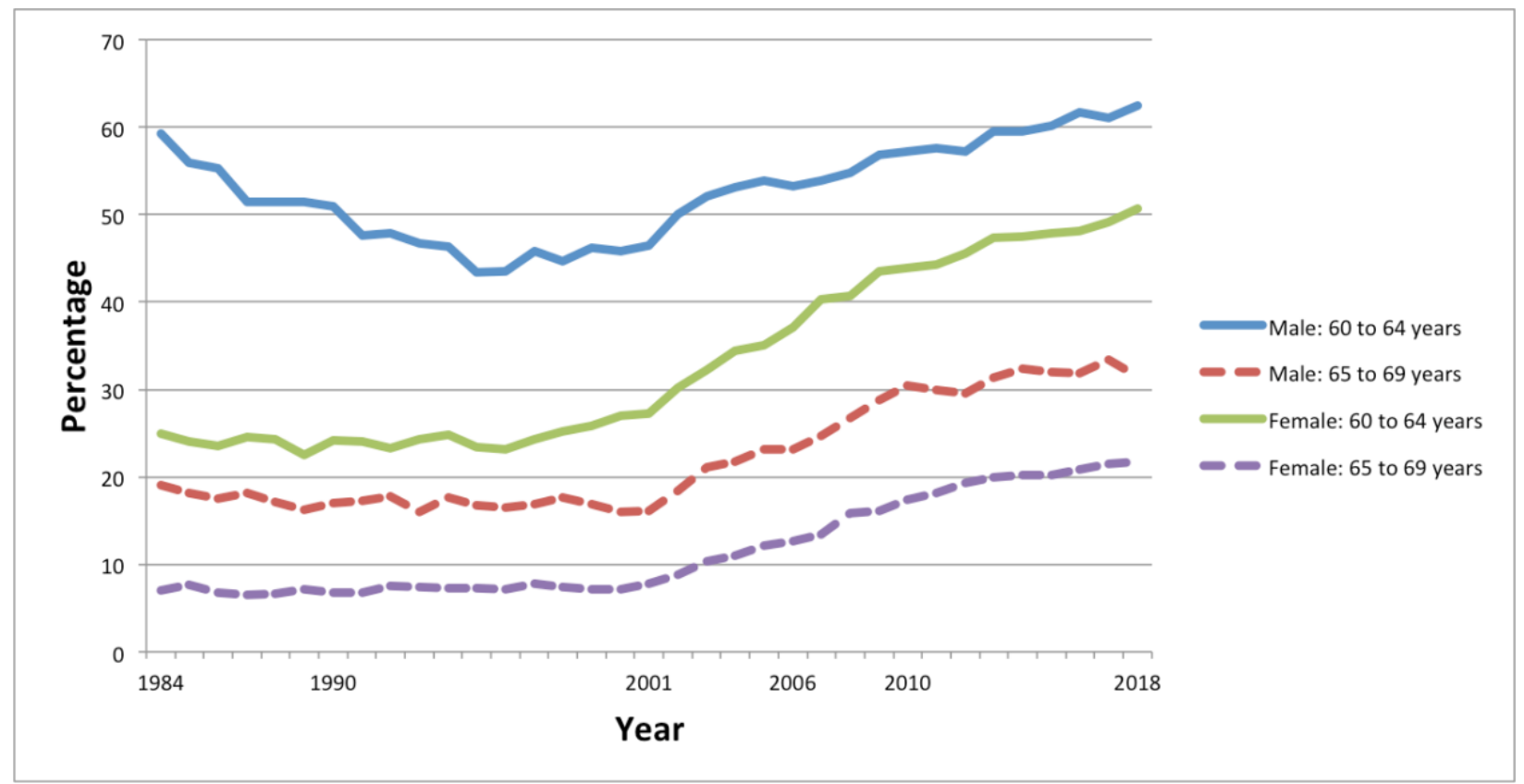

Source: Statistics Canada (2019). Table 14-10-0018-01 Labour force characteristics by sex and detailed age group, annual (x 1,000)

In his book Aging Workforce Demographics in Canada, author Steven Cronshaw (2012) predicts that Canada could see a normal age of retirement nearing 70 within 20 years. He states economic reasons for the delay that include savings, pension changes, and increasing dependency ratio mainly with dependents in the aging population. 
There is also a growing 'sandwich generation' where many older adults are caring for both grandchildren and aging parents. These factors increase family care expenditures and add pressure to delay retirement (Norris, 2013).

Older adults who have retired in Waterloo Region tend to be better prepared financially than elsewhere in Ontario; as such, they can expect less of a negative impact on spending and lifestyle upon retirement than previous generations or retirees in other areas (Waterloo Region, 2011). Even so, older adults in the region continue to work well past typical retirement age; however, not as many as the national average would suggest. Nation-wide, 24 per cent of the labour force is comprised of adults over the age of 65 (Statistics Canada, 2017e). In Waterloo Region, however, only about a 13 per cent of the workforce consists of older adults (Region of Waterloo, 2014). Including older adults in the workforce has significant benefits to employers and to the economy in general, benefits which the Waterloo Region is not experiencing to its full potential.

A noticeable trend is that adults who work past the age of 65 consume more both before and during retirement (Hicks, 2015). For example, in a scenario where a couple chooses to delay retirement for 10 years (i.e., retire at 73 instead of 63), the pair increases their lifetime income by at least 25 per cent. This couple expects to save for only 10 years of retirement, therefore increasing the amount of money they can spend both before and during retirement (Hicks, 2015). From a pure economic standpoint, more people working means more money being spent; but the benefits go far beyond direct dollar for dollar spending. If workers do not stay in the workforce past their 60s, the baby boom will cause pressures on the labour market with loss of small businesses, employees, skills, and experience en masse (IRP Taskforce on Aging, 2015).

\section{Older adult employees}

Research shows that employers experience increased performance, and decreased turnover for workers of all ages when workforces are composed of different generations (Neal and DeLaTorre, 2016). Older workers carry knowledge legacies and institutional memory, which can help employers preserve organizational effectiveness through business continuity, as well as by transferring knowledge to younger workers through mentoring and professional development opportunities. This is found to be beneficial for both the mentor and the mentee as the older worker feels valued and engaged, and the younger worker gains a lifetime of knowledge and experience from their mentor (Neal and DeLaTorre, 2016).

A study of older adults in the workforce found 80 per cent of older workers had 'bridge careers,' meaning they had either changed occupations or switched from full-time to part time status after the age of 55 (Neal and DeLaTorre, 2016). Flexibility and adaptability of both the labour market and the workers themselves is key to growing employment rates among older adults (2016). Employers who successfully support older workers reported creating a flexible working 
environment through flex hours, promoting personal-development programs, providing physical and mental activities, flexible schedules to accommodate the needs of workers who are also caregivers, and increased part-time work opportunities among older adults (Public Health Agency of Canada, 2017).

\section{Entrepreneurship}

Boomers are often considered to be more successful at building new businesses than the younger entrepreneurs (Badal and Ott, 2015). They bring a wealth of wisdom, trade experience, and a lower level of risk aversion to their endeavours (2015). In the USA, over 80 per cent of older adult entrepreneurs start new businesses either as a lifestyle choice or to boost their income (independence $32 \%$, interests and passions $27 \%$, income $24 \%$ ); only 10 per cent started their business because they saw a need in the market. Older adults are also twice as likely as millennials to plan or start a business because of these factors (2015). Older adults do experience similar obstacles to starting a news business as their younger cohorts. Access to credit, training, and coping with regulations are issues that can be addressed through innovations in small business advisor services for older adults to encourage more entrepreneurship among this eager age group (2015).

\section{Spending in retirement}

In his book Boom, Bust, and Echo, David Foot highlights that those in their 20s and 30s have little money and little savings, but have a significant need for goods and more time on their hands to seek out bargains (1996). Those in their 40s and 50s, have more money and more savings, but are generally consuming less and have less free time, therefore, they look for quality and service when making purchase decisions. Toward retirement, however, things change; retirees have more time on their hands, but are accustomed to quality and service. Incomes and health effects vary greatly among retirees; however, quality of life remains a consistent driver in older adult spending habits.

The average income for adults aged over 67 in Canada was \$38,659 in 2012 (Statistics Canada, 2017d). Household spending for this age group, however, averages $\$ 55,090$ annually. Primary expenses are shelter $(\$ 12,136)$, transportation $(\$ 7,443)$, recreation $(\$ 2,748)$ and direct healthcare costs $(\$ 2,038)$. On average, older adults spend $\$ 41,841$ on consumables, the remainder are taxes, insurance, etc. (Statistics Canada, 2017c).

\section{Health and Lifestyle Impacts on Spending}

Older adults are living longer and experience numerous life changes as they age, this can change their impact on the economy (Neal and DeLaTorre, 2016). In general, older adults can expect 
increased residential expenditures. Many are downsizing; renovating; or moving into group or care facilities as they progress in age, ability, and/or loss of a spouse or partner (Norris, 2013). This leaves a window of opportunity for developers, contractors, and long-term care providers to fulfill the greater demand for retirement-based residences/communities and group residential facilities. Long-term care facilities in particular have excellent economic potential; currently these facilities employ over 300,000 full time workers nation-wide in what is more than a six billion dollar industry (Public Health Agency of Canada, 2006).

The older adult's change in lifestyle has incredible market potential through the creation of new companies offering new products, services and technologies. There are big opportunities for growth in telemedicine, mobile health, regenerative medicine, 'anti-aging' products and treatments, and cognitive education/training to improve individuals' physical and cognitive health (Neal and DeLaTorre, 2016).

Aging at home and living a longer active life is also attributed to an increased interest in social connectedness, physical activity, healthy eating, fall prevention, and smoking cessation (Public Health Agency of Canada, 2006). All of these carry industry growth potential as the baby boom population continues to age.

\section{Built environment and age friendly communities}

In 2010, the World Health Organization (WHO) established the Age Friendly Community accreditation for municipalities that have increased efforts to become welcoming and safe for people of all ages through accessibility, housing, policy, transportation, and social inclusion measures (WHO, 2018; Neal and DeLaTorre, 2016). Accredited municipalities are required to deliver long-term commitments to continuous improvements as an age friendly society (WHO, 2018). These accreditation measures benefit people of all ages and particularly benefit older adult populations. Building age friendly communities keeps older adults healthier, more active, and more involved. These qualities are good for society as a whole as they help lower health care costs, increase labour force and volunteer participation among older adults, and greater older adult engagement in consumer behaviour (Public Health Agency of Canada, 2017b). The City of Waterloo holds such accreditation however; as of publication date, they are the only municipality within Waterloo Region to achieve this status (WHO, 2019).

There are many advantages to those municipalities that strategically work to attract older adults. Older adults contribute to the tax base that directly benefit the community and are less likely to use high-cost social services such as public schools (Feather, 2017). They are also known to maximize community recourses; retirees often go shopping, eat at restaurants, and ride public transportation at different times of the day than office workers or young families, equalizing revenue flow for local businesses throughout the day (2017). Older adults are also heavily 
involved in unpaid labour, this contribution benefits both their families and communities. 69 per cent of older adults are involved in some level of unpaid work, which helps to reduce childcare, health care, and social service costs (Public Health Agency of Canada, 2006). Adults aged 65-75 have the highest average reported number of volunteer hours across all age groups in Canada (Statistics Canada, 2019). In 201039 per cent of Canadians between the ages of 65 and 74 spend an average 235 hours per year volunteering, almost 80 more hours than the average (Vézina and Crompton, 2012). The economic value was determined to be $\$ 60.3$ billion per year at the time (Public Health Agency of Canada, 2006).

Beyond the monetary value, actively engaging older adults in the city planning and decisionmaking process has two main benefits. First, their point-of-view and experience can contribute to stronger planning that includes plans for age friendly community development (Public Health Agency of Canada, 2017b). Second, engaging older adults keeps them active in the community, which contributes to increased volunteerism, greater health effects and social connectedness, all of which have a positive impact on the economy (Public Health Agency of Canada, 2017b).

\section{Best practice evaluation}

According to their websites, the Region of Waterloo and its respective municipal Economic Development departments and small business centres do not currently promote programs or initiatives directly to or celebrating their older adult population (Cambridge, 2019; Kitchener, 2019; Region Of Waterloo Economic Development Corporation, 2019; City of Waterloo, 2019; Waterloo Region Small Business Centre, 2019). In most cases, all older adult services and initiatives reside within the Community Services (or similar) departments. There is great opportunity to include older adult services in strategic planning from the economic development offices. Numerous cities around North America are beginning to take this approach and are seeing economic benefits including increased job growth potential, and increased spending among older adults.

\section{Kansas City, Kansas}

Kansas City Economic Development has been watching the market potential related to older adults for some time. They have found that older adults (aged $65-74$ ) have lower wages than other age groups, however, their spending is still roughly equal (3\% less) to that of young adults aged 25-34 due to added income from savings and government programs (Kansas City, 2015). The metropolitan region used the Policy Insight model from Regional Economic Models Inc. and found retaining an additional 600 older adults for ten years in the region would result in a population increase of nearly 7000 people, and 2600 new jobs (Kansas City, 2015). The job growth would not only occur in the health care and retail sectors but also in the construction industry, as older adults tend to change to new housing at some point in their later lifespan, and 
this housing expenditure nearly equals that of younger adults entering the housing market (Neal and DeLaTorre, 2016).

\section{Kawartha Lakes, Ontario}

Twenty-five per cent of Kawartha Lakes population is aged 65 and older, significantly higher than provincial average of $16.7 \%$ (Statistics Canada, 2017f). Economic development has targeted age friendly business development as a growth opportunity for the area. The city has found older adults to be loyal customers who have 'purchasing power and time to shop' making them a valuable segment of the consumer market (Kawartha Lakes, 2018). Kawartha Lakes 'Age friendly' viewpoint is not limited to serving older adults; many changes can serve broader populations including persons with disabilities, parents with strollers, expectant mothers, and people with other limitations - plus some upgrades are just pleasant and welcoming to all customers (such as wider aisles, seating, and improved lighting).

Kawartha Lakes Economic Development has produced tools and guides to assist businesses with becoming age friendly, including:

- Wide and clutter free aisles

- Large print signs

- Accessible washrooms

- Respectful staff

- Good lighting

- Public washrooms

- Areas to sit

(Kawartha Lakes, 2018)

\section{London, Ontario}

The London Economic Development Corporation led a community steering committee in 2009 to develop a program titled, 'Experience Works'. This program was a two-part tool kit aimed at both employers and job seekers. This was one of several initiatives created to assist employers in considering and accessing various pools of talent and for older job seekers to develop successful approaches to seeking and obtaining employment (City of London, 2018).

This approach was found to be very successful, in 2016 London Economic Development Corporation continued with producing several two sided factsheets for broader distribution, and expanded the program to look at other pools of employment such as newcomers (R. Collins, personal communication, January 8, 2018). 


\section{Halton Region, Ontario}

The Halton Region Older Adult Plan 2015 - 2018 was produced by the Region's Community Services department; however, they worked closely with the Regional Economic Development staff to better serve the aging population workforce.

The plan's fourth priority revolves around supporting opportunities for older adults and how they can help Halton communities prosper. It has outlined the following objectives:

- Improving awareness about the impact of an aging population on Halton businesses and workplaces

- Surveying businesses to find out how employers are meeting the needs of older employees

- Determining the needs of older employees

- Including older adults in engagement around development and implementation of tourism plans

- Optimizing the participation of a regional workforce

- Ensuring internal Human Resources policies include older adult perspectives and supports

- Build Region capacity through encouraging older adults as mentors in the workplace

- Identify training to enhance staff skills when working with older adults: engaging and providing service to older adults

- Support older adults to work

- Support second careers

- Promote entrepreneurship or self-employment as viable option for older adults

- Support older adults to start and grow or buy a small business

(Halton Region, 2018)

\section{Recommendations}

How an aging society affects the Region of Waterloo's economy will depend on the actions taken by local decision makers now; the key is to harness the benefits of an aging society rather than letting opportunities pass by.

In Waterloo Region, a three-tier approach should be taken to maintain a healthy economy as its population ages: spending, employment, and services. These approaches can enhance existing strategies around building our young, innovative, and technology driven economy without hindering this work in any way. The creation of a detailed action plan could help the Region of Waterloo take advantage of all the economic and community benefits that come with an aging population. 


\section{Employment}

Economic Development and Small Business Centres should increase workshops and programs to help older adults' transition in 'bridge careers' and/or entrepreneurship. Economic efforts across the region must support the redefinition of 'retention' in the workplace to encourage flexible employment hours, locations, and opportunities. Area employers should strategically assess their workplace to see what opportunities fit best with the organization for older adults, coupled with support from the Region's Economic Development offices' through workshops and planning guides.

\section{Spending}

Business Improvement Areas, and Economic Development efforts should include a focus on growing retail and service sectors to include businesses of interest to older adults. Age friendly housing development, apartment sized furnishings, health care and anti-aging treatments/services, and social opportunities; all of these have high economic potential in an aging society. Furthermore, communities with depth in these market areas will attract older adults, helping to grow the population while increasing the strength and diversity of their economy.

\section{Services}

Waterloo Region should embrace the Age Friendly model to thrive as the population ages. Economic Development offices should work holistically with Community Services, Planning, Culture, and Housing departments to develop a robust model that attracts, retains, and engages older adults. This approach will keep older adults contributing as vital members of society, by providing them opportunities both to work longer, and to enjoy life. An age friendly model will ultimately result in a more robust economy for the region as a whole.

\section{Conclusion}

A society that values and supports the contributions of older adults, understands the benefits of population diversity, and ensures older adults are safe and respected with the services they require. Successful adaptation as the baby boom generation ages requires attention to these factors.

Waterloo Region should attempt to keep older adults living within the community as part of its economic growth strategy. Focusing solely on younger population growth would be detrimental to the long-term health of the Region's economy. According to Neal and DeLaTorre there are many factors at play when attracting and fostering older adult population growth; consideration 
of both the 'push' factors (loss of income, death of a family member, and changes in health) as well as 'pull' factors (retirement, neighbourhood amenities, new housing options) are needed to become an attractive community for older adults (2016). Waterloo Region has the right age friendly foundations; prioritizing policies and programs to keep older adults contributing members of society will help it to thrive through the baby boom aging effect.

\section{Author biography}

Tracy Suerich is currently a Project Coordinator at the Regional Municipality of Waterloo. Prior to discovering a passion for public service, Tracy had a long and prosperous career in arts administration. In 2009, that interest brought her to the City of Waterloo through the management of community festivals and events. Since that time, Tracy has pursued a broad range of opportunities in municipal government including economic development, community development, policy analysis, and stakeholder engagement in a path that has taken her from Waterloo to Newfoundland and back again. In 2013, Tracy received her master of Public Service from the University of Waterloo, and is currently focused on developing her career in economic development and strategic planning for the years to come. When not changing the world one community at a time Tracy enjoys golf, curling, scuba diving, camping and visual arts; with, whenever possible, her husband and dog in tow.

\section{References}

Badal, S. \& Ott, B. (2015, January 29). A Very Fast-Growing Group of Entrepreneurs: People Over 50. Gallup News. Retrieved from http://news.gallup.com/businessjournal/181352/fastgrowing-group-entrepreneurs-people.aspx

Cambridge (2019). Economic Development. Retrieved from

https://www.cambridge.ca/en/build-invest-grow/Economic-Development.aspx

City of London (2018). Retrieved from https://www.london.ca/residents/Seniors/AgeFriendly/Pages/Civic-Participation-and-Employment.aspx

City of Waterloo, The (2019). Economic Development. Retrieved from https://www.waterloo.ca/en/government/economic-development.aspx

Foot, D. (1996). Boom, Bust \& Echo, Toronto, ON: Macfarlane Walter \& Ross

Feather, J. (2017, December 6). Making the Economic Case for Age-Friendly Communities. Retrieved from https://www.huffingtonpost.com/john-feather-phd/age-friendlycommunities_b_11000368.html 
Halton Region (2018). Retrieved from

http://www.halton.ca/cms/One.aspx?portalId=8310\&pageId=91218

Hicks, P (2015). The Enabling Society. Institute for Research on Public Policy. Retrieved from http://irpp.org/research-studies/policy-horizons-essay-2015/

IRP Task Force on Aging (2015). Designing a National Seniors Strategy for Canada. Institute for Research on Public Policy. Retrieved from https://www.cma.ca/En/Lists/Medias/task-forceaging-report-e.pdf

Kawartha Lakes (2018). Age Friendly Business. Retrieved from http://www.kawarthalakes.ca/en/business-growth/Age-FriendlyBusiness.aspx?_mid_=23338

Kitchener (2019). Economic Development Strategy. Retrieved from https://www.kitchener.ca/en/city-services/economic-development-strategy.aspx

Neal, M and DeLaTorre, A, (February, 2016). The Case for Age Friendly Communities. Grantmakers in Aging. Retrieved from http://www.giaging.org/documents/160302_Case_for_AFC.pdf

Norris, D. (2013). Boomers: Ready or Not. Retrieved from http://www.regionofwaterloo.ca/en/regionalGovernment/resources/DOCS_ADMIN-1373989-v1doug_norris_presentation_boomers_ready_or_not.pdf

Public Health Agency of Canada (2006). Healthy Aging in Canada: A New Vision, A Vital Investment. Retrieved from http://www.phac-aspc.gc.ca/seniors-aines/altformats/pdf/publications/public/healthy-sante/vision/vision-eng.pdf

Public Health Agency of Canada, (2017). Chief Public Health Officer's Report on the State of Public Health in Canada 2014. Retrieved from https://www.canada.ca/en/publichealth/corporate/publications/chief-public-health-officer-reports-state-public-healthcanada/chief-public-health-officer-report-on-state-public-health-canada-2014-public-healthfuture/changing-demographics.html\#a5

Public Health Agency of Canada (2017b). Chief Public Health Officer's Report on the State of Public Health in Canada 2017. Retrieved from https://www.canada.ca/en/publichealth/services/publications/chief-public-health-officer-reports-state-public-health-canada/2017designing-healthy-living.html\#a6 
Region of Waterloo (2011). Waterloo Region Profile. Retrieved from http://www.regionofwaterloo.ca/en/regionalGovernment/resources/waterlooregionprofile.pdf

Region of Waterloo, (2014). Labour Force Report, Waterloo Region in 2014. Retrieved from http://www.regionofwaterloo.ca/en/doingBusiness/resources/2014_Labour_Force_Report.pdf

Region of Waterloo, (2019). Demographics. Retrieved on January 26, 2019 from https://www.regionofwaterloo.ca/en/doing-business/demographics.aspx

Region of Waterloo Economic Development Corporation (2019). Retrieved from https://www.regionofwaterloo.ca/en/economic-development.aspx

Statistics Canada, (2017a). Kitchener - Cambridge - Waterloo [Census Metropolitan Area] Onatrio and Ontario [Province] Census Profile. 2016 Census. Statistics Canada Catalogue no. 98-316-X2016001. Ottawa. Released November 29, 2017. Retrieved from http://www12.statcan.gc.ca/census-recensement/2016/dp$\mathrm{pd} /$ prof/details/page.cfm?Lang $=\mathrm{E} \& \mathrm{Geo} 1=\mathrm{CMACA} \&$ Code $1=541 \& \mathrm{Geo} 2=\mathrm{PR} \& \mathrm{Code} 2=35 \&$ Data $=$ Count $\&$ SearchText=kitchener $\&$ SearchType $=$ Begins $\&$ SearchPR $=01 \& B 1=A 11 \&$ TABID $=1$ (Accessed, December 6, 2017)

Statistics Canada, (2017b). Table 051-0056 Estimates of population by census metropolitan area, sex and age group for July 1, based on the Standard Geographical Classification (SGC) 2011, (table). Cansim (database). Retrieved from http://www5.statcan.gc.ca/cansim/a26?lang=eng\&id=510056 (Accessed November 14, 2017)

Statistics Canada (2017c). Table 203-0026 Household spending, by age of reference person (65+) (table). Cansim (database) Retrieved from http://www5.statcan.gc.ca/cansim/a26?lang=eng\&id=2030026\&p2=33 (Accessed November 26, 2017)

Statistics Canada (2017d). Table 115-0023 Sources of income for adults with and without disabilities, by age group and sex, Canada, provinces and territories+) (table). Cansim (database) Retrieved from http://www5.statcan.gc.ca/cansim/a26?lang=eng\&id=1150023\&p2=33 (Accessed November 14, 2017)

Statistics Canada (2017e). Table 282-0002 Labour force survey estimates (LFS), by sex and detailed age group (table). Cansim (database) Retrieved from http://www5.statcan.gc.ca/cansim/a26?lang=eng\&id=2820002\&p2=33 
(Accessed November 14, 2017)

Statistics Canada (2017f). Census Profile. 2016 Census. Statistics Canada Catalogue no. 98-316X2016001. Ottawa. Released November 29 2017. http://www12.statcan.gc.ca/censusrecensement/2016/dp-pd/prof/index.cfm?Lang=E

Statistics Canada (2019). Table 45-10-0012-01 Volunteer rate and average annual volunteer hours, by age group. Cansim (database) retrieved from

https://www150.statcan.gc.ca/t1/tbl1/en/tv.action?pid=4510001201 (Accessed January 20, 2019)

Vézina, M., \& Crompton, S. (2012). Volunteering in Canada (Canada Social Trends No. 93). Ottawa: Statistics Canada. Retrieved from https://www150.statcan.gc.ca/n1/en/pub/11-008x/2012001/article/11638-eng.pdf?st=bB_AvQY

Waterloo Region Small Business Centre (2019). Retrieved from https://www.waterlooregionsmallbusiness.com/

World Health Organization (2018). Age Friendly Cities Network. Retrieved from http://www.who.int/ageing/projects/age_friendly_cities_network/en/

World Health Organization (2019). Age Friendly World. https://extranet.who.int/agefriendlyworld/search-network/ 